\title{
Culturalismo e Experiência no novo Código Civil ${ }^{1}$ Judith Martins-Costa
}

\author{
Professora Adjunta na Faculdade de \\ Direito da UFRGS. Doutora em Direito.
}

\begin{abstract}
"Toda a pretensão de apresentar a Ciência do Direito independentemente de quaisquer pressupostos filosóficos, ou os subentende inadvertidamente, ou se resolve num equívoco agnosticismo filosófico que já equivale a uma contraditória tomada de posição especulativa" (Miguel Reale).
\end{abstract}

\section{Introdução}

1) A vocação prospectiva do novo Código: bases culturalistas. II) O Código como "razão comunicativa", ou o "modelo da complementaridade intertextual".

\section{Conclusão}

Em janeiro de 2003 entrou em vigor o novo Código Civil. Poder-se-ia questionar que importância tem esse acontecimento para um Congresso de Filosofia, cujo tema central diz com as "contribuições luso-brasileiras à filosofia". Desde já respondo a esta plausível indagação: a importância do novo Código para os fllósofos é que esse, em larga medida, concretiza, em bases normativas, a flosofia que o flósofo, jurista e codificador Miguel Reale assentou com o seu culturalismo em várias obras e, notadamente, em "O Direito como Experiência".

\footnotetext{
'Este texto é conseqüência de palestra proferida no IV Congresso Brasileiro de Filosofia, realizado en - João Pessoa, em agosto de 2002, cujas notas foram publicadas nos respectivos Anais, Tomo II, João Pessoa, 2002. Essa versão está publicada ern in Boletim da Faculdade de Direito, da Faculdade de Coimbra, vol. 78, pág. 126, Coimbra. Portugal, 2002. Agradeço a leitura e o sempre profícuo diálogo com Cláudio Michelon Jr.
} 
Nenhum Código provém do nada, nenhum código opera no vazio. O seu modelo sempre expressa uma reflexão $\mathrm{e}$ uma tomada de posição diante dos problemas do mundo - isto é, uma filosofia. As matrizes teóricas do novo Código Civil têm origem, justamente, no culturalismo de Reale, na sua concepção acerca dos modelos juridicos e da concreçãa ${ }^{2}$, no que chama, enfim, de "normativismo concreto". Vejamos, iniciaimente, a importância teórica dessa comprecnsão em nosso tempo, que rem sido definido como o tempo da pluralização da subjetividade jurídica, constituindo, portanto, o tempo da concrȩ̧ão.

Seja na filosofia, seja na sociologia, seja na teoria jurídica, várias análises se têm dedicado, recentemente, aos temas da intersubjetividade e da pluralização da subjetividade jurídica, que decorrem, como necessária consequência, da "transversalidade" que hoje recobre a fisionomia da sociedade civil ${ }^{4}$, da fissura do mito da igualdade formal que alicerçou a Codiffcação oitocentista, aliada ao reconhecimento da concreta diferença entre as pessoas è̀ atitude de aceitação da diferença. Decorre, fundamentalmente, de uma aceitação que não é a tolerância para com o mero faro da díferença (o que estaria subjugado apenas à dimensão da facticidade), constituindo, quanto ao muito, numa indiferença para com a diferença, para com a dimensão plural da subjetividade jurídica. Trata-se, diversamente, de acolher a diferença qualificadamente: é, pois, aceitação normativa, que opera segundo escolhas axiológicas. Nessa aceitação qualificada, é reconhecido que a diferença pode resultar da diversidade dos papéis sociais desempenhados por um mesmo individuo $0^{5}$; admite-se que o diferente pode,

2 Acerca do tema escrevemos, juntatnente com Gerson BRANCO, em Diretrizes Téricas do novo Código Civil, São Paulo, Saraiva, 2002.

"A saber, aquele em que a norma juridica não é concebida como simples estrutura lógico-formal, antes consistindo num "modelo ético-funcional que, intrínseca e necessariamente, prevế e envolve o momento futuro de una ação vetorial e prospectiva concreta". (REALE, Miguel, O Direito como Experiência, São Paulo, Saraiva, 1999, p. 191).

"A expressão é de IRTT, Natalino. Società Civile, Milão, Giuffè̀, 1992, p. 16. Assim indica o autor a "sintese de unidade e de multiplicidade" que concretiza a expressão "Estado pluralista", a cisão entre o 'cidadão' e o 'homem', a extraordinária variedade dos grupos sociais, de modo. que a "transversalidade" decompöe antigas e rigidas antíteses, reconstruindo uma nova fisionomia da sociedade civil.

5 A multiplicidade e a concomitância dos diferentes papéis sociais está ligada, em larga medida, à planiftcação, típica da racionalidade produtiva que caracteriza a nossa sociedade. Os confins do local do trabalho invadern o lar, espaço privado por excelência; os meios de comunicação de massa modificam os hábitos donésticos; a racionalidade produtiva transforma trabalhadores em consumidores, massifica;e automatiza e despersonaliza os negócios de troca (vide IRTI, Natalino. Società Civile, Milão, Giuffrè, 1992, pp. 18 e 19). A multiplicidade dos papéis sociais, a sua confusa concomitancia, acaba por deslocar e confundir a essencial compreensão individual do "papel no mundo" que cada um de nós desempenha. 
às vezes, receber maior tutela, ou uma tutela específica que atenda a sua diferença concreta; e a ordem jurídica se mostra atenta às singularidades de cada qual, polarizada pela idéia de "livre desenvolvimento da personalidade" num espaço que é, ou deve ser, concomitantemente, o espaço tutelar do indivíduo enquanto tal e como membro da comunidade, o "espaço comum" no qual podemos reconhecermo-nos como pertencentes à humanidade.

Alia-se a essa aceitação qualificada das diferenças subjetivas a concreção, que é a apreensão compósita da realidade (sempre processus histórico-cultural): é apreensão compósita porque conjuga, normativamente, os elementos fáticos e as diretrizes ideais, tendo em vista, porém, não o plano da abstração teórica, mas o da realidade prática que o Direito visa ordenar. É, portanto, o olhar axiológico direcionado para o concreto, para o que singulariza certo comportamento ou certa personalidade em suas particulares circunstâncias existenciais.

O emprego dos termos "diferença", "concreção", "pluralização" poderia, equivocadamente, conduzir o nosso pensamento à Teoria Pós-Moderna, fundada nos termos epígonos de Dertida, Lyotard, Baudrillard e Foucault ("diferença", "fragmentação", "desconstrução"), ligando-o ao que seria o fenômeno da ultrapassagem da modernidade". A pós-modernidade, afirma Arnaud, se caracteriza por um "desejo de ultrapassagem do paradigma moderno", por "uma vontade de pragmatismo e de relativismo", pelo afastamento, de modo especial, da categoria jurídica do sujeito de direito, numa radicalidade irracionalista que, para alérn de declarar a "decadência do Ocidente", como fez Spengler, chega a decretar o fim da história e a "morte do homem?". Não é, contudo, o que acontece com o novo Código Civill: não se pense que a aceitação da plural subjetividade jurídica, o "olhar para o concreto", signifiquem estejam as categorias abstratas expurgadas do Ordenamento, e que o projeto da modernidade tenha sido encerrado. A modernidade é um projeto inacabado, como percebeu Habernas com inteira lucidez". É preciso, antes de mais, conciliar os

${ }^{6}$ Entre os representantes das várias acepções dessa Teoria, veja-se, exemplificativamente, SANTOS, Boaventura: La transición postmoderna: derecho y política, in Doxa Cuadernos de Filosofia del Derecho,v. 6, 1989, pp. 223-263; BALLESTROS, Jesús, Razones a Favor de una Postmodernidad Alternativa (respuesta a Javier de Lucas), in Doxa - Cuademos de Filosofta del Dezecho,v. 6, 1989, pp. 301-306; ARNAUD, Andté-Jean, De la globalisation au postmodernisne en droit, em Entre modernité et mondialisation - Cinq leçons d'histoire de la philosophie du droit et de l'État, Paris, LGDJ, 1998, p. 147 a 178 e GHERSI, Carlos Alberto. Metodologias de la Investigación en Ciências Jurídicas, Buenos Aires, GOWA, 2001.

'ARNAUD, André-Jean. De la globalisation au postmodemisme en droit, em Entre modernité et mondialisation - Cing leçons d'histoire de la philosophie du droit et de l'ítat, Paris, LGDJ, 1998, p. 152. ${ }^{3}$ As referéncias são às teses de FUKUYAMA e de FOUCAULT, confirmadas por ARNAUD, que é explícito: "Passada a moda da filosofia "moderna", fala-se do surgimento do pós-modernismo, e, com ele, de "desconstruçāo", de "morte do homem" (ARNAUD, André-Jean. De la globalisation au postmodernisme en droit, em Entre modernité et mondialisation - Cing leçons d'ristoire de ha philosophie du droit et de l'Etat, Paris, LGDJ, 1998, p. 147 e 148, traduzimos).

"HABERMAS, Jürgen. O Discurso Filosófico da Modernidade. Lisboa, Dom Quixote, 1998, Prefácio. 
"Deuses Lares" com o "espírito do mundo", respondendo ao dilema proposto, admiravelmente, por Juan Gris: "Sans l'abstrait, comment dominer le concret? Et sans le concret, avec quoi dominar l'abstrait" ?" É preciso, em suma, numa atitude fundamentalmente moderna $a^{12}$, aceitar o dilema e equacionar, racionalmente, o desafio: como normatizar, de modo abstrato e getal, as plurais relações intersubjetivas na vida da cives? Como ordená-las segundo padrões de uma substantiva racionalidade, que leve em conta as concretas características das situações jurídicas intersubjetivas a serem ordenadas?

No que concerne às relações civis, equacionar esse desafio é a tatefa cometida a um Código dotado de uma nova racionalidade; não mais a "razão monológica" do Iluminismo, não mais a ratio totalitária e fechada, que desconhece as pulsões e os desejos do indivíduo dissolvido na massa, que escamoteia as substanciais desigualdades econômicas e o jogo de poder que se desentola na vida da cives, mas uma racionalidade aberta e substantiva, capaz de submeter "à sua jurisdição o reino dos valores" e de avaliar "a maior ou menor racionalidade das normas"13". Registre-se: ainda, e mais do que nunca, uma racionalidade, e não a irracionalidade, a "verrigem ${ }^{14 \text { " }}$ que são conjuntamente com o relativismo - as águas nas quais navega o pós-modernismo ${ }^{15}$.

50 A metáfora é de SEBRELI, Juan José. Ei Asedio a la Modemidad-critica del relativismo cultural, Buenos Aires, Sudamericana, 1991, ao referir-se à "Filosofia do Direito", de Hegel, segundo o qual, "o espirito dos povos, as naçōes, os deuses-lares, estavam limitados por sua particularidade e deviam submeter-se ao juízo universal, ao espírito do mundo, à história universal erigida em um tribunal supremo"'(p. 25)

"GRIS, Juan, citado por HABIB, Claude, na Introduction à tradução francesa da obra de ARENDT, Hannah, Penser l'événement, Paris, Bélin, 1989, p. 15, ein tradução livre: "Sem o abstrato, como dominar o concreto?/ E sem o concreto, con o que dominar o abstrato?".Paris, LGDJ, 1998, p.149. 12 Porque a filosofia moderna ensinou, fundamentalmente, que temos que pensar por nós mesmos, 0 que está na base do sapere aude kantiano e de toda a possibilidade de uma atitude crítica, que é sempre utna atitude ditada pela razão. Refiro-me, naturalmente, à "razào dos modernos", que inaugura uma linha: a da "razão iluminista", hoje insuficiente (como adiante tentarei explicar), mas não passível de substituição pela sua antítese, o irracionalismo.

${ }^{13}$ ROUANET, Sérgio Paulo, As razóes do lluminismo, São Paulo, Companhia das Letras, $7^{2}$ reimpressảo, 2000, P. 12.

${ }^{14}$ A expressão é de ARNAUD, André-Jean, De la globalisation au postmodernisme em droit, em Entre modernité et mondialisation - Cing leçons d'histoire de la philosophie du droit et de l'État, Paxis, LGDJ, 1998, p. 149.

is Afrma Anthony CARTY, cirado por ARNAUD: "A Lei, con um L mailisculo, a Razāo, com um $\mathrm{R}$ maińsculo, o Homem, com um $\mathrm{H}$ maiúsculo, formam una Trindade defunta"(ARNAUD, AndréJean, De la globalisation au postmodernisne em droit, em Entre modernité et mondialisation -.. Cing leçons d'histoire de la philosophie du droit et de l'tetat, Paris, LGDJ, 1998, p. 149, traduximos e grifamos). Acerca do irtacionalismo como marca cultural do pós-modernismo, veja-se, ainda, SEBRELI, Juan José, El Asedio a la Modernidad- critica del relativismo cultural, Buenos Aires, Sudamericana, 1991, pp. 25 a 42, traçando a genealogia entre os pré-tomânticos alemăes (notadamente HERDER), que contrapunham o local ao universal, e o irracionalismo filosófico (SPENGLER, PEYRABAND), e político que veio, a final, percorrendo os caminhos da filosofía é́clica e catastrófica da história, desembocar no nazismo. Veja-se, ainda, a hícida análise de ROUANET, Sérgio Paulo, As fazões do Iluminisno, São Paulo, Companhia das Letras, $7^{2}$ reimpressäo, 2000. 
Operacionalizar as formas de manifestação dessa nova racionalidade é a missão que hoje incumbe a um Código Civil, que deve ser apto a tealizar o equilíbrio entre as formas de regulação abstrata e geral - tendo em conta o princípio da segurança jurídica - e as formas de tegulação casuística e plural, para tanto considerando, com um relevo especial, as circunstâncias do caso, as singularidades do livre desenvolvimento da personalidade, a efetiva desigualdade substancial das partes contratantes, tendo em conta o princípio da justiça substancial. E é justiça "substancial" porque não tem como pressuposto uma noção abstrata de sujeito de direito, mas tem como base cultural a idéia do Direito como "experiência normada" e, como base axiológica "o indivíduo situado", a pessoa humana considerada como "o valorfonte de todos os valores" 17 ", tese que Reale desenvolve desde 1940 e à qual reputa "um papel fundamental" em seu pensamento, como fulcro do que denomina de "historicismo axiológico"1s.

O desafro de normatizar as plurais relações intersubjetivas na vida da cives com base na concreção, perpassa todo o novo Código Civil, seja através de sua linguagem (que alia modelos cerrados e modelos abertos ${ }^{10}$ ), seja em razão das soluçōes metodológicas que adota, viabilizadoras de uma intertextualidade com outros corpos normativos. Essa opera por meio de ligações inter, intra e extra sistemáticas com os valores do Ordenamento, notadamente aqueles expostos na tábua axiológica dos Direitos Fundamentais. Tal é a concepção subjacente ao que tenbo chamado de "a Era da Recodificação", en contraponto ao célebre título dado por Irti, nos anos 70 , aos ensaios que detectavam a opção de políticajuridica, então ocorrente, da descodificação ${ }^{20}$. É uma concepção radicalmente diversa da que orientou o Código de 1916, embasado no positivismo compreendido ao modo das Ciências Naturais.

Tenrarei provar esse argumento com algumas considerações acerca da base culturalista das soluções do novo Código (1), oferecendo, após, alguns exemplos das formas de comunicação entre o Código e as demais instâncias culturais, o que, ao meu ver, é, caracteristicamente, uma opção culturalista (II).

\footnotetext{
í REALE, Miguel, "De Dignatate Jurisprudentiae", in Horizontes do Direito e da História, São Paulo, Saraiva, 1977 , p. 275, chegando mesmo a afirmar não ser adequado, a rigor, sequer falar em "norma e situação normada" porque "a norma é, ao mesmo tempo, o condicionante e o condicionado, o valor e o fato em uma sintese dinâmica" (idem, ibidem).

${ }^{77}$ REALE, Miguel, Fundamentos do Direito, São Paulo, Revista dos Tribunais, $3^{2}$ edição fac-simile da $2^{2}$ edição revista, 1998 , p. 305.

${ }^{17}$ REALE, Miguel, Fundamentos do Direito, Säo Paulo, Revista dos Tribunais, $3^{a}$ edição fac-simile da $2^{3}$ edição revista, 1998 , p. 305, nota 26 a.

${ }^{19}$ Examinei o Código sob essa perspectiva in O Direito Civil como um "sistema em construçāo"-as cláusulas gerats no Projeto do Código Civil Brasileiro, em Revista dos Tribunais, v. 753, São Paulo, jul. 1998.

${ }^{20}$ IR'TI, Natalino, L'età della decodificazione, Milão, Giuffrè, $3^{2}$ edição, 1989.
} 


\section{I) A vocação prospectiva do novo Código: bases culturalistas.}

Das contribuiçôes brasileiras para a fllosofia, é o culturalismo a mais televante. Seu campo de atuação é privilegiadamente o do Direito, seja em razão de suas filiações históricas (nas quais avultam Tobias Barreto e a Escola do Recife), seja pela força do pensamento de Reale, agora consagrado legislativamente.

O que caracteriza o culturalismo é a adoção da noção de cultura como "paradigma central" nos domínios das ciências humanas. Não se trata, porém, de uma visão estratificada e estática da cultura: Reale aplica ao mundo da cultura o esquema da teoria tridimensional, segundo a qual toda experiência histórico-social é "uma forma resultante da correlação tensional entre fatos e valores ${ }^{2 n I}$, para, assim, alcançar os três direcionamentos fundamentais da sua pesquisa acerca da cultura, a saber: a) uma telativa aos elementos factuais que condicionam a ação humana ${ }^{22}$; b) outra relativa aos valores efins já adquiridos, ou intencionados a adquirit, dando origem a valorizaçôes que se objetivam em bens historicamente constituídos; $\mathrm{e}, \mathrm{c}$ ) outra pertinente às formas que os bens culturais assumem, no curso da história ${ }^{23}$. Esses três direcionamentos não são seccionáveis, pois Reale rejeita o "fragtmentarismo reducionista que caracterizou toda a cultura individualista burguesa ${ }^{24 "}$, compreendendo a cultura como totalidade e como processo, o que não leva, porém, a eliminar a tesponsabilidade do homem na ação, mas a compreendê-la pela concreção, que é sempre, e necessariamente, contextual. Daí a sua afirmação de que "nenhuma estrutura cultural é uma ilha"2.5 estando no cerne da cultura a interdisciplinatiedade, a processualidade, a dialeticidade e a integralidade, pois "a vida cultural não se ordena segundo 'in fra-estruturas' e 'superestruturas', mas sim segundo 'momentos' de um processo ${ }^{2(3)}$, polarizado pela dialética da complementaridade.

\footnotetext{
27 REALE, Miguel, O Homem e seus Horizontes, São Paulo, Topbooks, $2^{a}$ edição, 1997, p. 20, grifos Jo autor.

22. Dirá, enr Fundamentos do Direito: "o jurista move-se com certa liberdade na esfera do construído, mas nāo pode deixar de se subordinar ao dado". "dado", porém, "pode ser natural, histórico, racional ou ideal". (REALE, Miguel, Fundamentos do Direito, São Paulo, Revista dos Tribunais, $3^{\text {a }}$ edição fac-simile da $2^{2}$ edição revista, 1998, p. 297).

${ }^{23}$ REALE, Miguel, O Homem e seus Horizontes, São Paulo, Topbooks, $2^{2}$ edição, 1997, p. 20.

${ }^{24}$ REALE, Miguel, Fundamentos do Direito, São Paulo, Revista dos Tribunais, $3^{2}$ edição fac-simile da $2^{2}$ edição revista, 1998 , p. 291.

${ }^{25}$ REALE, Miguel, O Homem e seus Horizontes, São Paulo, Topbooks, $2^{2}$ edição, 1997, p. 21.

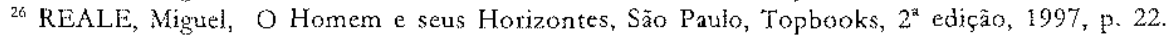


Em face dessa ordenação processual, integral, interdisciplinar e dinâtmica da cultura, as objetivaçōes culturais "não se vetificam sempre da mesma forma" ${ }^{\text {"27 }}$. Intuição e razão, ordem e desotdem, desejo e vontade, acaso e necessidade, continuidades e descontinuidades, estão compostos na cultura. É preciso distinguir entre a experiência cultural pré-categorial e a experiência cultural intencionalmente ordenada ou predicativa, categorias que, por sua vez, tambérn não são estanques ${ }^{28}$, mas intercorrelacionadas. Daí que, embora na experiência cultural intencionalmente ordenada seja mais pronunciada e efetiva a contribuição racional ${ }^{29}$, a cultura se apresenta como um verdadeiro a priori do conhecimento e da ação humanas. Dirá Reale:

"Assim sendo, desde o mais elementar ato de percepção, o percebido já surge como algo objetivo e transpessoal, de tal modo que jamais logratíamos compreender o significado do homem desvinculado do complexo variegado daquilo que ele exterioriza, como projeção e dimensão imediata de sua consciência intencional. É a razão pela qual costumo afirmar que a cultura é o sistema aberto das 'intencionalidades objetivadas', de tal sorte que o homem só pode ser integralmente compteendido levando-se en conta o que ele é como indivíduo 'a se' e o que ele é como sócio, isto é, enquanto partúcipe consciente ou não do complexo de imagens, símbolos, fórmulas, leis, instituiçöes, etc., ou seja, de todas as formas que, no decurso do tempo, vão assinalando a incessante incidência de valores sobre o já dado ou positivado na história ${ }^{30 " .}$

A cultura é, em suma, o a priori - absolutamente não-estático - que define a nossa forma de set, de conhecer, de compreender, de sentir e de regular as nossas relações, inclusive juridicamente. Pottanto, para conhecer é necessário năo apenas tet em conta o objeto do conhecimento ou o sujeito cognoscente, mas a circunstancialidade em que o conbecimento se process $a^{31}$. Daí o a priori cultural, o qual não é, todavia, absoluto ou imutável: toda a cultura é histórica, constituindo, sempre, um processo de realização de valores ${ }^{32}$ que se compõem, continuamente, na dimensão do tempo cultural $l^{33}$.

Nesse universo cultutal dinâmico, processual, integrativo e interdisciplinar, o Direito é, por sua vez, "uma espécie de experiência cultural", "uma realidade que resulta da natureza

${ }^{27}$ REALE, Miguel, O Homem e seus Horizontes, São Paulo, Topbooks, $2^{2}$ edição, 1997, p. 22.

${ }^{28}$ Pelo contrário, afirma, "ambas coexistem permanentemente, influenciando se de maneira recíproca"

2" REALE, Miguel, (REALE, Miguel, O Homem e seus Horizontes, São Paulo, Topbooks, $2^{*}$ ediç̧̃ão, 1997, p. 23).

${ }^{30}$ RliLle, Miguel, O Homem e seus Horizontes, São Paulo, Topbooks, $2^{2}$ edição, 1997, p. 25, grifos do autor e nossos.

31 Entre outras obras de Reale que tratan do "a priori cultural" veja-se Paradigmas da Cultura Contemporânea, Säo Paulo, Saraiva, 1996.

32 REALE, Miguet, Paradigmas da Cultura Contemporânea, Săo Paulo, Saxaiva, 1996, p. 6.

3. Assim o nosso"Direito e Cultura: entre as veredas da existência e da história", em Diretrizes Teóricas do Novo Código Civil, MARTINS-COSTA, Judith e BRANCO, Gerson, São Paulo, Saraiva, 2002. 
histórica e social do homem", apresentando-se sempre como "síntese ou integração do ser e do dever-ser, de fatos e de valores, quer em experiências particulares, quer na experiência global dos ordenamentos objetivados na história" ${ }^{34}$. Daí que, para o culturalismo, o Direito só é compreensível como bem cultural, consistindo o momento normativo no momento da concreção de fatos e valores.

É bem verdade que esse "momento normativo" pode ter início na experiência da vida social; porém, essa experiência vai continuamente merecendo a atenção do legislador e dos órgãos jurisdicionais, sendo integrada pelas escolhas axiológicas dos órgãos que têm o poder de decidir: assim são recolhidas, e estruturadas em modelos jurídicos, as normas derivadas do "poder social", expresso nos usos e costumes e na autonomia privada, bem como o poder estatal (poder de legislar e o poder de exercitar a jurisdição). Os usos, a autonomia negocial, a legislação e a jurisdição constituem as quatro fontes que expressam a objetivação dos modos de sentir, de pensar e querer, culturalmente conformados.

Porém, essa objetivação - que é o ato de tornar algo objetivo, distinto do sujeito criador $^{35}$ - não se esgota num só momento, ela é processual e prospectiva: através de variados modos de comportamento (o exercício da autonomia privada, no plano negocial; reiterados modos de ser e entender, consolidados nos usos e costumes; a repetição de julgados dos Tribunais e as decisões do legislador), desenvolve-se a experiência normativa do Diteito, que é experiência ditada pela cultura, e "sob cuja luz devem ser aferidos os contratos, obedecidos os costumes, obedecidas as decisões judiciais e cumprida a lei ${ }^{36 "}$ ".

Mas esta "experiência normativa do Direito" - sendo cultural e axiológica (pois a cultura é processo de objetivação de valores) - não pode ser vista de modo formal, como quis o positivismo formalista: tem que estar atada à experiência bumana concreta, à experiência de uma determinada sociedade, em determinado momento de sua história. Como dirá Novaes - ainda que sob diversa perspectiva flosófica - há sempre a relação da razão com a "carne do mundo"(expressão de Merleau-Ponty), o que está a significar que, na ordem da razão, devemos perceber que "o mundo sensivel e o mundo histórico [são] sempre intermundo"37. Em outras palavras, "o acesso ao mundo se dá não apenas através do 'espírito interior', por meio da reflexão, mas também através do espírito difundido nas relações históricas e no mundo humano 38 ": como também observou Metleau-Ponty, "não

\footnotetext{
${ }^{34}$ REALE, Miguel, O Direito como Experiência, São Paulo, Saraiva, 1999, p.p. 111 e 112.

${ }^{35}$ REALE, Miguel, O Direito como Experiência, São Paulo, Saraiva, 1999, p. XXì

${ }^{37}$ REALE, Miguel, O Direito como Experiência, São Paulo, Saraiva, 1999, p. XXnt.

${ }^{36}$ REALE, Miguel, O Direito como Experiência, São Paulo, Saraiva, 1999, p. XXil.

38 NOVAES, Adauto, em A lógica Atormentada, em A Crise da Razão. (org.). NOVAES, Adauto, São Paulo, Companhia das Letras, primeira reimpressão, 1999 , p. 16.
} 
há o homem interior", na medida em que a relação do cogito "exige de nós experiência ${ }^{3 y " .}$ Uma experiência, porém, que não é apenas vivida, não é apenas fato - é uma experiência significativa.

O formalismo abstrato, no Direito, ignorando essa percepção, é uma "perversão", diz Reale, decorrente da cisão entre as estruturas predicativas (experiência cultural intencionalmente ordenada) e a experiência cultural pré-categorial, que constitui o "húmus fecundante da vida comum espontânea" ${ }^{30}$. Por isto o autor realiza a distinção e a correlação entre as fontes cos modelos no Direito.

Essa distinção/correlação é a que existe entre retrospectividade e prospectividade, entre estabilidade e processualidade, entre o que é ou foi, e o que vem a ser. As fontes são estáticas, derivando do poder de decidir atribuído à lei, à jurisdição, ao poder negocial e ao costume. A idéia de modelo, diversamente, está ligada à de "projeto", de "planificação lógica" e de "representação lógica e antecipada dos resultados a serem alcançados por meio de uma seqüência ordenada de medidas ou prescrições" $\$$. Daí que os modelos jurídicos, "não são meras criações da mente, mas sim o resultado da ordenação racional do conteúdo das normas reveladas ou formalizadas pelas fontes de direito, para atender aos característicos de validade objetiva autônoma e de atualização prospectiva dessas mesmas normas" ".

Em suma: a modelagem da experiência jurídica é feita pelo jurista "em contato direto com as relações sociais" "43. Contudo, diferentemente do sociólogo, que descreve e explica as relações sociais, o jurista opera mediante normas que não são causais ou motivacionais, mas "produzidas segundo o processo correspondente a cada tipo de fonte que espelha a solução exigida por cada campo de interesses ou valores"44. Assim sendo, a atitude do jurista é racional e axiológica: as fontes e os modelos estão articulados, mas essa articulação não é de modo nenhum estática ou seccionada: trata-se de um processo complexo e racional de articulação enrre as normas derivadas das várias fontes e modelos, o que pode produzir

39 NOVAES, Adauto, em A lógica Atormentada, em $A$ Crise da Razão. (org.). NOVAES, Adauto, São Paulo, Companhia das Letras, primeira reimpressão, 1999, p.p. 16 e 17.

* NOVAES, Adauto, em A lógica Atormentada, em $A$ Crise da Razäo. (org.). NOVAES, Adauto, São Paulo, Companhia das Letras, primeira reimpressăo, 1999, p. 17. A referência é ao prefácio, de MERLEAU PONTY, à Fenomenologia da percep̧ão.

${ }^{41}$ REALE, Miguel, Fontes e Modelos no Direito - para um novo paradigma hermenêutico, São Paulo, Saraiva,1994, p. 40.

${ }^{42}$ REALE, Miguel, Fontes e Modelos no Direito - para um novo paradigma hermenêutico, São Paulo, Saraiva, 1994, p. 40.

${ }^{43}$ REAle, Miguel, Fontes e Modelos no Direito - para um novo paradigma hemenêutico, São Paulo, Saraiva,1994, p. 41.

${ }^{44}$ REALE, Miguel, Fontes e Modelos no Direito - paxa um novo paradigma hermenêutico, São Paulo, Saraiva, 1994, P. 41. 
variadas combinações, tudo polarizado, porém, pelos valores constitucionais ${ }^{45}$, ao qual acresce a contribuição - entre nós relevantíssima ${ }^{45}$ - dos modelos hermenêuticos, ou doutrinátios, seja na colmatação de lacunas, seja no efetivo desenho dado à modelagem prescritiva, ao "projeto normativo" a realizat. Assim sendo, um verdadeito sistema aberto de retrospectividades e de prospectividades exprime, em diversas e convergentes dimensões, a coexistência, no Direito, da experiência cultural pré-categorial e da experiência cultural predicativa. Reale diz:"sempre me impressionou o fato de que o povo criador do Direito (Romanos) não foi um escravo da lei, como mandamento do Estado, mas antes um criador de fórmulas ordenadoras no bojo da sociedade civil mesma; na medida em que os fatos iam ditando, e a necessidade ia exigindo soluções notmativas, eram os jurisconsultos que forneciam aos litigantes a formula iuris que o praetor convertia em norma iuris através de sua decisão ${ }^{47}$."

Portanto Reale vê o Direito como ordenação racional e processual da experiência bumana, segundo certas necessidades, ditadas pelas efetivas relações sociais, e de acordo com determinados valores ${ }^{48}$, que se afirmam e confirmam no tempo cultural. Por isto, dirá: "aos olhos do jurista o Direito se põe prevalecentemente como norma, mas esta não pode deixar de ser considerada uma realidade essencialmente histórica: mas as normas jurídicas não são o mero reflexo do fato, não são o "retraro sintético do fato": elas envolvem uma tomada de posição opcional e constitutiva por parte de quem as positiva, à vista do fato e segundo critérios de valor ${ }^{42 *}$.

\footnotetext{
${ }^{45}$ Esclarece Reale: "se o ordenamento jurídico não tem a graduação lógica atribuída à Kelsen ao sistema do Direito nacional e internacional, reconhece-se, geralmente, que, em virtude de sua subsunção à mesma ordem constitucional, ele se constitut, tudo somado, como unidade coerente e complementar, cujas lacunas e contradições é mister superar"( REALE, Miguel, Fontes e Modelos no Direito - para um novo paradigma hermenêutico, Săo Pauło, Saraiva,1994, p. 41). A unidade é, porém, in fieri, e resulta da complementaridade dos modelos juridicos que se pöem, processualmente, de modo "aberto" no ordenamento (idem, ibidem).

4 Procurei a centuar o peso da modelagen doutrinária entre nós (o que é uma característica verdadeiramente nacional) em "A Boa-Fé como Modelo", em MARTINS-COSTA, Judith, e BRANCO, Gerson. Diretrizes Tétricas do novo Código Civil, São Paulo, Saraiva, 2002, p. p.191-193. 47 REALE, Miguel, O Direito como Experiência, Säo Paulo, Saraiva, 1999, p. XXIII.

4反̂ Já na sua obra de 1940 (Fundamentos do Direito), Reale propõe uma crítica ao positivismo - uma crítica que o ultrapasse, tão se limitando à mera negação e enfrenta o problema especifico da experiencia jurídica, questionando: Como é, em suma, que o jurista parte dos fatos, que "sāo", para atingir a esfera daquilo que "deve ser"? Ora, como já havia dito Kant, não podemos encontrar, na simples verificaçāo daquilo que $\hat{e}_{,} a$ indicação do que deva ser, sendo essa uma verdade que não se pode contestar." Propõe, en conseqüencia, uma teoria do conhecimento que esteja atenta a todos os aspectos da realidade, já que toda a compreensão parcial da experiencia determina uma compreensão parcial do real. Esta Teoria do Conhecimento desemboca na noção de experiencia, que é um conceito complexo, não-redutivel ao factual, ao dado sensivel, mas como um conceito que, atendendo à dialeticidade e a historicidade do conhecimento, não desconhece o fator preponderante do valor no processo cognoscitivo (estabelecendo a ligação entre fato/valor/norma e a experiência). \$9 REALE, Miguel, O Direito como Experiência, Sảo Paulo, Saraiva, 1999, p. 201.
} 
Isto é, o "momento normativo" do Direito se vai permanentemente modificando, constituindo um processo que nâo se esgota num só momento, nem está com os olhos voltados ao passado, ao momento da posição da norma na fonte: ele é prospectivo, devendo estar aberto às transformações nos modos de sentir, de pensar, e querer pelos quais a pessoa humana, valor-fonte do Ordenamento, se afirma, concomitantemente, como individuoe como membro da comunidade.

A sua noção do Direito como ordenação da experiência bumana segundo certos valores - ordenação que se faz de modo prospectivo, dinâmico, processual e integrativo - perpassa todo o novo Código Civil, e está rraduzida na sua estrutura e na noção de sistema que contém.

Esse é, agora, o viés de meu exame, para tentar demonstrat como operam, em dimensão prospectiva, as higações intra, extra intersistemáticas que permitem a comunicação entre as normas do próprio Código, os fatos da vida social, e os valores do Ordenamento.

\section{II) O Código como "razão comunicativa", ou o "modelo da complementaridade intertextual".}

A razão está no centro da atitude moderna, palavra que, desde o século $\mathrm{V}$ (quando surge no léxico ocidental), possui a conotação de uma "descontinuidade proposital do novo diante do antigo"50, para expressar a consciência de uma nova época ${ }^{51}$. E está no centro dessa atitude porque há, entre razão e crise, estreito parentesco etimológico ${ }^{52}$, e porque en nossa época, como em qualquer outra, só a razão é crítica, porque "seu meio vital é a negação de toda a facticidade"5.3. o irracionalismo, seu oposto, é sempre conformista, "pois seu modo de funcionar excluí o trabalho do conceito, sem o qual não há como dissolver o existente" ${ }^{54}$.

\footnotetext{
50 HABERMAS, Jürgen, Concepçōes da Modernidade - um olhar retrospectivo sobre duas tradiçōes, em A Constelação Pós-Nacional - Ensaios Políticos, tradução de Márcio Seligmann-Silva, São Paulo, Littera Mundi, 2001, p. 168.

51 HABERMAS, Jürgen, Concepçōes da Modernidade - um othar retrospectivo sobre duas tradiçōes, em A Constelação Pós-Nacional - Ensaios Políticos, tradução de Márcio Seligmann-Silva, São Paulo, Littera Mundi, 2001, p.168

52. Como explica BORNHEMM, a origem grega da palavra crise e de seus derivados (critica, crítico, critério) está ligada ao verbo krino,que apresenta os seguintes significados: 1) escolher, separar, distinguir, discernir o verdadeiro do falso; 2) julgar, pronunciar um julgamento; 3) decidir, pronunciar. Na voz média, significa escolher, decidir, julgar, explicar, disputar. (BORHEMM, Gerd. Crise da idéia de crise, em A Crise da Razão. (org.). NOVAES, Adauto, São Paulo, Companhia das Letras, primeira reimpressão, 1999 , p. 49). Já o termo razão, o latino "ratio", "logos", em grego, também quer dizer "julgar", "faculdade de pensar" - "pensar" que é "pesar", decidir, como acentua NOVAES, Adauto, en A lógica Atormentada, em A Crise da Razão. (org.). NOVAES, Adauto, Sāo Paulo, Companhia das Letras, primeira reimpressão, 1999, p. 11.

5.3 ROU N NET, Sérgio Paulo, As razões do Iluminismo, São Paulo, Companliza das Letras, $7^{\mathrm{x}}$ reimpressāo, 2000 , p. 12 .

5. ROUANET, Sérgio Paulo, As razões do Iluminisno, São Paulo, Companhia das Letras, $7^{2}$ reimpressāo, 2000 , p. 12.
} 
A razão tem sido rejeitada quando tomada como uma sinédoque: à palavra "razão" parece ter sido colada a etiqueta da razão cartesiana, ou da razão formal, submetida exclusivamente à jurisdição da lógica formal, ou da razão instrumental, ocupada com os meios, e não com os fins. Espírito fundan te da modernidade iluminista, Descartes acoplou a idéia de razão à de unidade, pretendendo revesti-la de um estatuto autônomo: "Da mesma forma que o Sol é o único sol que ilumina todas as coisas, a razão também é única", dirá Husserl, citando Descartes em sua famosa "Conferência de Viena" $a$ ", do que decorrerá, como conseqüência, o totalitarismo da razão única, monológica, já que a ideologia totalitária se reduz à "lógica de uma idéía" que convence mediante o encadeamento de deduções a parrir de uma premissa falsa ou mentiros $a^{56}$. Porém, não devemos seguir a perigosa trilha da sinédoque, tomando a parte pelo todo: agora já não mais se trata de uma subserviência à razão iluminista, totalitária e excludente, nem da razão instrumental, "cuja competência se

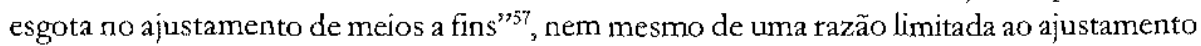
às categorias da lógica formal, que se ocupa da forma, mas não da subsrância ${ }^{58}$. A nossa modernidade requer uma razão sensível, substantiva, processual e comunicativa. Esclareçamos essas expressões:

A razão sensível é a que ultrapassa a tradicional cisão entre o sujeito e o objeto, percebendo o intermundo de Merleau-Ponty ${ }^{59}$. É o que, em outras palavras, apontara Reale, ao situar a relação entre ohịeto do conhecimento e o sujeito cognoscente na "circunstancialidade em que o conbecimento se processa ${ }^{60 "}$ ", isto é, na experiência não apenas vivida, mas tomada como fonte de extração de sentidos. A razão substantiva é aquela capaz de pensar fins e valores ${ }^{61}$, a que considera o homem como um projeto sujeito a condicionalismos, por certo, mas voltado à concreção de virtudes. E, por fim, a razão processual e comunicativa é a que não se fecha sobre si, não é axiomática, mas está aberta ao devir e à interação das instâncias culturais.

\footnotetext{
55 A referência está em NOVAES, Adauto. A lógica atormentada, em $\Lambda$ Crise da Razão. (org.). NOVAES, Adauto, São Paulo, Companhia das Letras, prineira reimpressão, 1999, p. 13.

${ }^{56}$ A proposição, que é de Hannah $A R E N D T$, fó retomada por LEFORT, Claude. O imaginário da crise, em A Crise da Razão. (org.). NOVAES, Adauto, São Paulo, Companhia das Letras, primeira reimpressão, 1999, p. 29.

57 ROUANET, Sérgio Paulo, As xazões do Iluminismo, São Paulo, Companhia das Letras, $7^{2}$ reimpressão, 2000, p. 12.

${ }^{58}$ Acerca das insuficiências da razão, entendida como categoria exclusivamente lógico-formal para o trabalho do jurista, vejarse HABA, Enrique. Racionatidad y Método para el Derecho: es eso posible? Em Doxa, vols. 7 e 8,pp.169-247 e 241.269, Aficante, 1990.

59 Citado por NOVAES, Adauto. A lógica atormentada, em A Crise da Razão. (orr.). NOVAES, Adauto, São Paulo, Companhia das Letras, primeira teimpressão, 1999 , p. 16.

${ }^{6}$ Entre outras obras de Reals que tratam do "a priori cultural" veja-se Paradigmas da Cultura Contemporânea, São Pacilo, Saraiva, 1996.

"ROUANET, Sérgio Paulo, As razōes do Iluminismo, São Paulo, Companhia das Letras, $7^{2}$ reimpressão, 2000 , p. 12.
} 
Por isto é que, em contraposição ao irracionalismo que domina a Teoria Pós-Moderna, proponho - recepcionando a expressão de Habermas, que alude à razão comunicativa ${ }^{62}$. compreender-se, contemporaneamente, a categoria da razão como denotativa de uma racionalidade atenta aos condicionamentos materiais e psíquicos da ação humana, aos entrelaçamentos entre saber e poder, postos a nu por Max, Freud, Adorno e Foucault $t^{63}$, e, portanto, de uma racionaljdade elástica, não-axiomática, e, bem assim, flexivel, que conduza a um método jurídico dotado das mesmas virtudes ${ }^{64}$. Daí a idéia de uma "racionalidade comunicativa". E dai porque os instrumentos que a expressam, juridicamente, devem estar abertos à intertextualidade, permitindo a construção de mecanismos de freios e contrapesos a esses condicionalismos.

Essas conotações dadas à razão, em nossa modernidade, parecem-me adequadas para visualizar, do ponto de vista metodológico, o novo Código Civil, evidenciando o que nele deriva do culturalismo de Reale. A idéia de a experiência jurídica se ir continuamente formando e completando, em acordo aos dados culturais prevalecentes dados da comunicabilidade humana - está expressa na estrutura, na metodologia e na linguagem do novo Código Civil. Esta é diversa da empregada no Código de Bevilaqua que encerrava, ainda, (perfazendo o modelo da Codificação oitocentista), a "razão totalitária" ou monológica, fundada na pretensão de completude lógica e legislativa que acabou realizando o modelo da incomunicabilidade.

O novo Código, pelo contrário, atento à processualidade da experiência, instaura a "razão comunicativa" a situar a permanente, mas coordenada, intertextualidade entre o seu corpus e outras fontes, juridicas e extra-jurídicas, produtoras de normatividade social, conformando, pois, o modelo da complementaridade intertextual.

${ }^{62}$ HABERMAS propõe, na verdade, a categoria da "ação comunicativa" e de uma "racionalidade comunicativa" (vide Teoria de la Acción Comunicativa - racionalidad de la acción y racionalización social, tradução de Manoel Jiménez Redondo, Madri, Taurus, $2^{2}$ edição, 2001, pp. 70 a 136), expressões que, no contexto de sua obra, conotam a idéía de ser a razão validada consoante o contexto,e na medida em que aceita num processo argumentativo, levado a cabo sem deformaçŏes externas ou internas. Em síntese muito apertada, HABERMAS propõe operar a razão num meio lingüistico que se reflete, como tal, nas relaçōes entre o homem e o mundo. A ação humana, concomitantemente situada no tnundo objetivo e no mundo subjetivo, é uma ação reflexiva, situando-se, então, a problemática da racionalidade, como um "mecanismo de coordenação da ação humana". Utilizo a expressão "razão comunicativa" em outro contexto filosófico porque é diverso, na comparação entre HABERMAS e REALE, o papel e a compreensão da cultura, embora a expressão, por sí só, pareçame de grande expressividade para situar a idéia do Código como uma ordenação jurídica flexivel e racional, processual e interdisciplinat, "comunicativa", nessas acepçŏes, com as demais instânzias culturais.

${ }^{63}$ Veja-se a análise de ROUANET, Sérgio Paulo, As razões do lluminismo, São Paulo, Companhia das Letras, $7^{\mathbf{a}}$ reimpressão, 2000, p. 12 e ss.

${ }^{64}$ Não se confunda, porém, "racionalidade" e "método", embota, por vezes, os dois termos apareçam equívocos, como adverte HABA, Entique. Racionalidad y Método para el Derecho: es eso posible? Em Doxa, vol. 7, p. 171 e 172. 
Essa comunicação intertextual está fundada em bem determinados princípios - o da socialidade, da eticidade e da operabilidade -, e é possibilitada pela conexão entre a estrutura (fundada numa Parte Geral que inicia com a invocação não-taxativa dos Direitos da Pessoa, seguida de uma Parte Especial constituída por cinco Livros, todos eles correlacionados à Parte Geral) e uma linguagem aberta ${ }^{65}$.

A abertura semântica é garantida pela existência de cláusulas gerais estrategicamente colocadas, permitindo a apreensão de três ordens de conexão sistemática, a saber: a) conexões intra-sistemáticas; b) conexões intersistemáticas; c) conexões extra-sistemáticas.

Tradicionalmente o Código - o Código oitocentista, portador da "razão rotalitária", excludente de quaisquer fórmulas de comunicação entre o jutídico e as demais instâncias sociais - comportava tão somente conexões intra-sistemáticas. Isto significa dizer que as suas normas, quando não-vistas como mônadas leibnizianas, interagiam quase que exclusivamente entre si. A comunicação com as demais notmas do Ordenamento operava exclusivamente ao modo formal, segundo os cânones da lei no tempo, da lei no espaço, e da hierarquia das fontes legislativas.

A concepção realeana dos modelos jurídicos provoca uma substancial modificação nesse rígido esquema formal. Não apenas as normas se estruturam como modelos, estando abertas para o futuro, como os modelos interagem entre si, numa complexidade ordenada e sinalizada pelo valor a tornar concreto na situação a ser resolvida. Tomo como exemplo a modclagem da tesponsabilidade civil.

O modelo anterior, do Código de 1916, concentrava no art. 159 os pressupostos e a conseqüência da responsabilidade subjetiva (dever de indenizar). Nos arts. 1.518 a 1.532 estava a definição de algumas espécies.

Agora, na Parte Geral, dão-se apenas as condições da ilicitude - um dos pressupostos da responsabilidade civil (arts. 186 e 187) - cujo conteúdo material é renovado: a ilicitude não é apenas "ilegalidade", não está atada exclusivamente à conseqüência indenizatória, pressupõe uma idéia de direito subjetivo como integração de liberdades coexistentes, como algo que já nasce "conformado" no jogo de ponderações entre os diferentes princípios que se põem como vetores axiológicos fundamentais do ordenamento. Assim, deve ser conctetizada a noção de ilicitude a partir de conceitos semanticamente abertos, como "conduta contrária a boa-fé", ou "ato desviado do fim econômico-social do negócio"

\footnotetext{
${ }^{65}$ Para o exame da estrutura e da linguagem do novo Código, permitimo-nos remeter ao texto " $O$ Novo Código Civil - em busca da "ética da situação", em MARTiNS-COSTA, Judith, e BRANCO, Gerson. Diretrizes Teóricas do novo Código Civil, São Paulo, Saraiva, 2002, Pp. 95-130.

${ }^{6}$ Para o exame da estrutura e da linguagem do novo Código, permitimo-nos remeter ao texto "O Novo Código Civil - em busca da "ética da situação", em MARTINS-COSTA, Judith, e BRANCO, Gerson. Diretrizes Teóricas do novo Código Civil, São Paulo, Saraiva, 2002, pp. 95-130.
} 
extraordinatiamente o campo semântico da ilicitude à vista de determinados valores objeto da tutela do ordenamento jurídico para coibir-se o uso inadmissível de posições jurídicas.

Como se percebe, a diferença do modelo anterior (que conotava automaticamente a ilicitude civil ao dano e ao dever de indenizar) é imensa. Se na Parte Geral estão as condições da ilicitude (arts. 186 e 187), a obrigação de indenizar ganhou autonomia (arts. 927 a 943), demonstrando que, embota seja a mais corriqueira e televante consequiência da ilicitude civil, não é, contudo, o seu único efeito. Sepatadamente, tratou-se da indenização (arts. 944 a 954 ).

Marquemos o significado da autonomização da obrigação de indenizar, que encontra paralelo no Código Civil português. Como assinala Almeida Costa, em referéncia ao Código Português, "trata-se de uma importante novidade de ordem sistemática" num único instituto, os princípios relativos aos efeitos da responsabilidade civil, que são comuns às suas várias modalidades (contratual, extracontratual, pré-negocial, pós-negocial, subjetiva, objetiva). Essa disciplina unitária abarca universo extenso, recortando-se, no Título IV, a responsabilidade que deriva do inadimplemento de obrigação, a qual, todavia, não está afastada, seja ontologicamente, seja na principiologia e em numerosas regras concernentes ao regime jurídico do universo geral da responsabilidade por danos.

$\Lambda$ esta estrutura inovadora combina-se um novo conteúdo material. Para além do alargado campo da ilicitude, antes apontado, foram incorporados, à responsabilidade civil, vários princípios dotados de elevada carga axiológica: exemplificativamente, o princípio da eqüidade, estabelecido no parágxafo único do art. 928, em caso de dano causado por incapaz; o princípio da proporcionalidade, contido no parágrafo único do art. 944; o princípio da gravidade da culpa concorrente da vítima, posto no art. 945 , e ainda as regras especiais a certos tipos de dano dos atts. 948 a 954, além da importantíssima cláusula geral de responsabilidade objetiva pelo risco, a teor do parágrafo único do art. 927 , assentada na noção de estrutura social.

É justamente aí, no parágrafo único do art. 927, que está mais fortemente marcada a concepção culturalista. O novo Código institui espécie de cláusula geral de responsabilidade objetiva ao determinar o nascimento do dever de indenizar, independentemente de culpa, não apenas nos casos especificados em lei, mas também 'quando a atividade normalmente desenvolvida pelo autor do dano implicar, por sua natureza, risco para os direitos de outrem'.

${ }^{67}$ ALMEIDA COSTA, Mário Júlio. Direito das Obrigaçōes. 8. ed. Coimbra: Almedina, 2000. p. 692. 
Em outras palavras, é a noção metajurídica de 'atividade normalmente exercida pelo autor do dano, que implique risco', a ser necessariamente concretizada pelo intérprete, que definirá qual o regime aplicável à responsabilidade, o que permite a construção progressiva de várias espécies de responsabilidade por danos, conformando uma visão prospectiva da experiência jurídica, da norma como "experiência normada".

Em suma, a estrutura dada à responsabilidade civil enseja traçar conexões intrasistemáticas (sendo preciso, para definir o regime aplicável, conectar várias normas do Código); intersisremáticas (reenviando para outros estatutos normativos, como a Constituição, em tema de danos à pessoa, ou ao Código de Processo Civil); e extra-sistemáticas (atirando para fora do sistema jurídico, avaliando, por exemplo, a proporcionalidade entre a conduta culposa e o efetivo dano, segundo dados estatísticos). Do desenlıo traçado por essas conexões é que, conforme a situação de fato e do valor incidente, modelar-se-á a normativa incidente, e se estabelecerá a medida do dever de indenizar.

Aliás, o Código é pródigo ao estabelecer conexões extra-sistemáticas, enviando o intérprete para fora do sistema jurídico na medida em que deve buscar dados nos demais sub-sistemas sociais (Sociologia, Engenharia, Economia, Medicina, Estatística, Biologia, Informática, etc.,) para completar a estatuição das normas "parcialmente em branco" que contém, conferindo, assim, amplo espaço de concreta normatividade aos usos e direcionando a autonomia privada à função social e a outros dirames éticos, como a boa-fé ( $v$.g, arts 113, $128,187,421,422)$.

Por fim a nova lei requer, permanentemente, a conexão com elementos intersistemáticos, o que marca a sua intertextualidade. Tomo como exemplo o art. 21, segundo o qual "a vida privada da pessoa natural é inviolável, e o juiz, a requerimento do interessado, adotará as providências necessárias para impedir ou fazer cessar ato contrário a esta norma": isto está a significar que o juiz tem o dever de determinar a providência que, à vista das circunstâncias, entenda mais adequada à otimização do conteúdo da norma protetiva, podendo essa providência consistir na adoção de medida cautelar, antecipatória da tutela defirritiva, a imposição de astreintes, de obrigação de não-fazer, de perdas e danos ou outras medidas contidas no Código de Processo Civil.

Daí sairá desenhado o modelo concreto - a perfazer-se naquele caso - da ligação intersistemática entre o Código Civil e a garantia constitucional fundamental à vida privada e à intimidade, e também com as normas processuais, que são um importantíssimo meio de dar efetividade aos direitos fundamentais, possibilitando abarcar casos de ferimento à vida privada que são hoje, porventura, recnicamente inimagináveis.

Observa-se, portanto, que o Código já não sintetiza todo o Direito Civil - e nem pretende fazêlo. Ele requer uma permanente complementação com as demais nomas do sistema, em especial com os Direitos Fundamentais, que espelham a tábua de valores essenciais do sistema, a partit do assentamento de um valor de base, estruturante e 
fundante de todos os demais: o da dignidade da pessoa humana, o "valor fonte" de todos os valores. Daí a idéia de "construção permanente", que é tipicamente culturalista: não uma construção conceitual ao modo pandectista, mas uma construção atada à experiência social concreta, à "ética da situaçãa ${ }^{680 "}$.

\section{Conclusão:}

\section{Qual a importância da tradução legislativa da concepção culturalista?}

Penso que nessa nossa época de relativismo cultural e de louvação do irracionalismo, um Código culturalista tem a virtude de insraurar um novo padrão de racionalidade no Direito Privado.

Autores como Habermas ${ }^{69}$, Finkielkraut ${ }^{70}$, Sebreli $^{71}$ e Rouanet $^{72}$ têm um ponto em comum: opõem à vertigem irracionalista, ao relativismo cultural (que é, et pour cause, relativismo axiológico) e à postura anti-histórica (porque marcadamente historicista), a racionalidade como única via para o exercício da crítica, para a não-submissão à facticidade, para o não-conformismo, para a aberrura de uma ordem que é taxionomia, ordem humana, humanamente arranjada.

Concordando com esses aurores, penso que o novo Código tem a missão, fundamental, de assegurar a racionalidade no Direiro. Mas penso, igualmente, que essa é uma racionalidade que não é mais aquela da razão iluminista ou monológica,que marcou a Codificação oitocentista.

\footnotetext{
68 Assim o nosso "O Novo Código Civil Brasileiro: Em Busca Da "Ética Da Situação", em Diretrizes Teóricas do Novo Código Civil, MARTINS-COS'TA, Judith e BRANCO, Gerson, São Paulo, Saraiva, 2002.

as Veja-se, em especial, HABERMAS, Jürgen. Teoria de la Acción Comunicativa - racionalidad de la acción y racionalización social, tradução de Manoel Jiménez Redondo, Madrid, Taurus, $2^{a}$ edição, 2001; A Constelação Pós Nacional - Ensaios Políticos, tradução de Márcio Seligmann-Silva, São Paulo, Littera Mundi, 2001;

79 FINKIELKRAUT, Alain, La défaite de la pensée, Paris, Gallimard, 1987.

7 SEBRELI, Juan José. El Asedio a la Modernidad - critica del relativismo cultural, Buenos Aires, Sudamericana, 1991.

${ }^{72}$ ROUANET, Sérgio Paulo, As razões do Yuminismo, São Paulo, Companhia das Letras, $7^{*}$ teimpressão, 2000,
} 
Uma racionalidade comunicativa - como a que o novo Código pode assegurar - não interdita a possibilidade de controvérsias, motivo pelo qual o raciocínio tópico não lhe é adverso: os princípios, insertos nas cláusulas gerais do Código, funcionam como loci, como pontos de partida para a formação do raciocínio, como "lugares-comuns" para o andar em tomo ao problema, na busca de sua solução ${ }^{73}$. Esssa racionalidade não se quer matematicamente lógica, nem burocraticamente instrumental: ao contrário, tem "jurisdição sobre o mundo

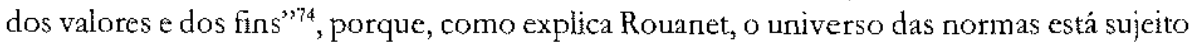
aos mesmos critérios de racionalidade processual que o universo dos fatos e "nos dois casos, só a argumentação racional pode decidir da validade de uma afirmação que se pretende verdadeira, ou de uma norma que se pretenda justa ${ }^{75}$ ".

Por que um Código aberto, polarizado por valores, é apro para instrumentalizar esta razão? Em outras palavras, em que medida essa metodologia e uma nova linguagem, fundada em princípios e cláusulas gerais, assegura ao Código Civil uma "racionalidade comunicativa" fundada numa ética de princípios?

Penso que assim ocorre porque o Código configura um sisterna aberto e móvel, sendo dotado das válvulas de abertura axiologicamente orientadas. As suas cláusulas gerais, conectadas à sua estrutura, permitem a imediata captação dos valores, notadamente aqueles expressos na tábua axiológica dos direiros fundamentais, e a sua difusão no interior do seu próprio corpus, desta feitta por meio das ligações intra-sistemáticas. Daí que o Código enseja ao intérprete/aplicador do Direito o dever, e a responsabilidade, de formular, a cada caso, a estatuição, para o que deve percorrer o ciclo do reenvio, buscando em outras normas do sistema ou em valores e padrões extra-sistemáticos, os elementos que possam preencher e especificar a moldura vagamente desenhada na cláusula geral. Em conseqüência, as cláusulas gerais situam o Código no plano da concretude e auxiliam a concrerizar os Direitos Fundamentais na dimensão da experiência jurídica, dinamicamente considerada como dimensão da cultura.

É dimensão da concretude porque, viabilizando a "ética da situação" - o indivíduo situado, e não o ser abstrato" * permite, pela concreção judicial dos modelos abertos, a constante alteração do significado e do conteúdo de uma disposição codificada sem modificar a sua letra, evitando, assim, os males da inflação legislativa e da rigidez que, narcando o

\footnotetext{
${ }^{73}$ Tentei demonstrar essa possibilidade ao examinar o raciocínio que tem sido empregado em relação ao princípio da boa-fé objetiva en A Boa-Fé no Direito Privado, São Paulo, Revista dos Tribunais, 1999, pp. $364-377$.

74 ROUANET, Sérgio Paulo, As razóes do Iluminismo, São Paulo, Companhia das Letras, $7^{2}$ reimpressão, 2000, p.15.

${ }^{75}$ ROUANET, Sérgio Paulo, As razōes do Iluminismo, São Paulo, Companhia das Letras, 7" reimpressão, 2000, p. 15.

${ }^{76}$ REALE, Miguel, O Código Civil e seus Problemas Fundamentais, Säo Paulo, Saraiva, 1986.
} 
modelo dos códigos oitocentistas, ensejaram o seu distanciamento do "direito vivente", da experiência juridica concreta. Só assim, pode o Código Civil cumprir com a sua responsabilidade ética e política de garantir a unidade mínima - conceitual e valorativa - sem a qual se recai numa espécie de neo-exegetismo das leis especiass ${ }^{77}$, cada uma sendo entendida como um átomo, mil átomos apontando a direções diversas. Nessa perspectiva, pode o Código assumir a responsabilidade, ética e política, de completar a Constituição, desenvolvendo a função de garantia e proteção da vida civil ${ }^{78}$, e anuando como "o fio da tazão ordenadora" ${ }^{79 ", ~ e m ~ t o r n o ~}$ da qual desenvolve-se a nossa listótia das relaçôes privadas.

O Código Civil já não tem, agora, o caráter constitucional que tinha na experiência oitocentista, mas retorna ao centro do sistema para cumptir a função de garantia e assumir a responsabilidade de unificar (melhor dirfamos: de larmonizar) o caos irracional dos mícrossistemas ${ }^{80}$, promovendo a comunicação, racionalmente ordenada, entre os Direitos Fundamentais e as instâncias normativas infra-constitucionais. Na crise instaurada pela globalização - que é imposição política da (des) razão do mercado - o Código se apresenta, enfim, como continuidade da cives, continuidade axiológica, porém, continuidade nãolinear, porque os valores que encerra - da socialidade, eticidade e operabilidade - estão em permanente teferência histórica.

\footnotetext{
7 Alerta IRTl que o fenômeno da descodificação e a emergência de leis especiais, que se movem sob o impulso das contingências econômicas ou das emergências politicas, "estranhas a qualquer escrúpulo técnico ou preparação doutrinária, "si esauriscono nella lettura esegetica", condurindo a métodos de neo-exegese. (en Códice Civile e Società Politica, Ronna, LATERZA, $3^{*}$ ediçăo, 1999. p. 48).

78 IR'TI, Natalino, em Códice Civile e Società Política, Roma, LATERZA, $3^{2}$ edição, 1999. p. 14.

"A expressão é de IRTl, Natalino, em Códice Civile e Società Política, Roma, LATERZA, $3^{2}$ ediçâo, 1999 . p. 70.

Bu Assim observa IRTI, Natalino, em Códice Civile e Società Política, Roma, LATERZA, $3^{*}$ edição, 1999. P. 15.
} 


\section{REFERÊNCIAS BIBLIOGRÁFICAS} 2000 .

ALMEIDA COSTA, Mário Júlio. Direito das Obrigações. 8. ed. Coimbra: Almedina,

ARENDT, Hannah. Penser l'événement, Paris, Bélin, 1989.

ARNAUD, Aridté-Jean. De la globalisation au postmodernisme en droit, em Entre modernité et mondialisation - Cinq leçons d'bistoire de la philosophie du droit et de l'État, Paris, LGDJ, 1998.

BALLESTROS, Jesús. Razones a Favor de una Postmodernidad Alternativa (respuesta a Javier de Lucas), in Doxa-Cuadernos de Filosofia del Derecho, v. 6, 1989, pp. 301-306.

BORHEIM, Gerd. Crise da idéia de crise, em A Crise da Razão. (org.). NOVAES, Adauto, São Paulo, Companhia das Letras, primeira reimpressão, 1999, pp. 47-66.

FINKIELKRAUT, Alain. La défaite de la pensée, Paris, Gallimard, 1987.

GHERSI, Carlos Alberto. Metodologias de la Investigación en Ciencias Juridicas, Buenos Aires, GOWA, 2001.

HABERMAS, Jürgen. Teoria de la Acción Comunicativa - racionalidad de la acción y racionalización social, tradução de Manuel Jiménez Redondo, Madrid, Taurus, $2^{a}$ edição, 2001.

HABERMAS, Jürgen. Concepções da Modernidade - um olhar retrospectivo sobte duas tradições, em A Constelação Pós-Nacional - Ensaios Políticos, tradução de Márcio Seligmann-Silva, São Paulo, Littera Mundi, 2001.

HABA, Entique. Racionalidad y Método para el Derecho: es eso posible? Em Doxa, vols. 7 e 8,pp.169-247 e 241-269, Alicante, 1990.

HABERMAS, Jürgen. O Discurso Filosófico da Modernidade. Lisboa, Dom Quixote, 1998.

IRTI, Natalino. L'età della decodificazione, Milão, Giuffrè, $3^{a}$ edição, 1989.

IRTI, Natalino. Società Civile, Milão, Giuffrè, 1992.

IRTI, Natalino.Códice Civile e Società Política. Roma, LATERZA, $3^{a}$ edição, 1999.

LEFORT, Claude. O imaginário da crise, em A Crise da Razão. (org.). NOVAES, Adauto. São Paulo, Companlia das Letras, primeira reimpressão, 1999, pp. 27-46. 
MARTINS-COSTA, Judith. O Direito Civil como um "sistema em construção"-as cláusulas gerais no Projeto do Código Civil Brasileiro, em Revista dos Tribunais, v. 753, São Paulo, jul. 1998.

MARTINS-COSTA, Judith, e BRANCO, Gerson. Diretrizes Teóricas do novo Código Civil, São Paulo, Saraiva, 2002.

NOVAES, Adauto. A lógica atormentada, em A Crise da Razão. (org.). NOVAES, Adauto, São Paulo, Companhia das Letras, primeira reimpressão, 1999, Pp. 9-18.

SANTOS, Boaventura: La transición postmoderna: derecho y política, in DoxaCuadernos de Filosofia del Derecho, v. 6, 1989, pp. 223-263.

REALE, Miguel.O Direito como Experiência, São Paulo, Saraiva, 1999.

REALE, Miguel. Fontes e Modelos no Direito - para um novo paradigma bermenêutico, São Paulo, Saraiva,1994.

REALE, Miguel. O Código Civil e seus Problemas Fundamentais, São Paulo, Saraiva, 1986.

REALE, Miguel. "De Dignatate Jurisprudentiae", in Horizontes do Direito e da História, São Paulo, Saraiva, 1977.

REALE, Miguel. Fundamentos do Direito, São Paulo, Revista dos Tribunais, $3^{a}$ edição fac-simile da $2^{\mathbf{a}}$ edição revista, 1998. 1997.

REALE, Miguel.O Homem e seus Horizontes, São Paulo, Topbooks, $2^{a}$ edição,

REALE, Miguel. Paradigmas da Cultura Contemporânea, São Paulo, Saraiva, 1996.

ROUANET, Paulo Sérgio. As razóes do lluminismo, São Paulo, Companhia das Letras, $7^{\text {a }}$ reimpressão, 2000.

SEBRELI, Juan José. El Asedio a la Modernidad-critica del relativismo cultural, Buenos Aires, Sudamericana, 1991. 